This item was submitted to Loughborough's Research Repository by the author.

Items in Figshare are protected by copyright, with all rights reserved, unless otherwise indicated.

\title{
Mixing theory for culture and harvest in bioreactors of human mesenchymal stem cells on microcarriers
}

PLEASE CITE THE PUBLISHED VERSION

http://dx.doi.org/10.1134/S0040579516060117

\section{PUBLISHER}

Springer ( Pleiades Publishing

\section{VERSION}

AM (Accepted Manuscript)

\section{PUBLISHER STATEMENT}

This work is made available according to the conditions of the Creative Commons Attribution-NonCommercialNoDerivatives 4.0 International (CC BY-NC-ND 4.0) licence. Full details of this licence are available at: https://creativecommons.org/licenses/by-nc-nd/4.0/

\section{LICENCE}

CC BY-NC-ND 4.0

\section{REPOSITORY RECORD}

Nienow, Alvin W., Qasim A. Rafiq, Thomas R.J. Heathman, Karen Coopman, and Christopher J. Hewitt. 2017. "Mixing Theory for Culture and Harvest in Bioreactors of Human Mesenchymal Stem Cells on Microcarriers". figshare. https://hdl.handle.net/2134/25736. 


\title{
Mixing Theory for Culture and Harvest in Bioreactors of Human Mesenchymal Stem Cells on Microcarriers
}

\author{
A. W. Nienow ${ }^{1,2^{*}}$, Q. A. Rafiq ${ }^{2,3}$, T. R. J. Heathman ${ }^{2}$, K. Coopman ${ }^{2}$, C. J. Hewitt ${ }^{2,3}$ \\ ${ }^{I}$ School of Chemical Engineering, University of Birmingham, Birmingham, B15 2TT, UK; \\ ${ }^{2}$ Centre for Biological Engineering, Loughborough University, Loughborough,LE11 3TU, UK \\ ${ }^{3}$ Aston Medical Research Institute, School of Life and Health Sciences, Aston University, Birmingham, B4 7ET, \\ $U K$ \\ "e-mail: $\underline{\text { a.w.nienow@bham.ac.uk }}$
}

\begin{abstract}
The use of human mesenchymal stem cells (hMSCs) in regenerative medicine is a potential major advance for the treatment of many medical conditions, especially with the use of allogeneic therapies where the cells from a single donor can be used to treat ailments in many patients. Such cells must be grown attached to surfaces and for large scale production, it is shown that stirred bioreactors containing $\sim 200 \mu \mathrm{m}$ particles (microcarriers) can provide such a surface. It is also shown that the just suspended condition, agitator speed $N_{J S}$, provides a satisfactory condition for cell growth by minimizing the specific energy dissipation rate, $\varepsilon_{T}$, in the bioreactor whilst still meeting the oxygen demand of the cells. For the cells to be used for therapeutic purposes, they must be detached from the microcarriers before being cryopreserved. A strategy based on a short period ( $\sim 7 \mathrm{~min})$ of very high $\varepsilon_{T}$, based on theories of secondary nucleation, is effective at removing $>99 \%$ cells. Once removed, the cells are smaller than the Kolmogorov scale of turbulence and hence not damaged. This approach is shown to be successful for culture and detachment in 4 types of stirred bioreactors from 15 $\mathrm{mL}$ to $5 \mathrm{~L}$.
\end{abstract}

Key words: Mesenchymal stem cells; Bioreactors; Microcarriers; Growth; Suspension; Detachment. 


\section{INTRODUCTION}

The use of stem cells for regenerative medicine is a potential major advance in the treatment of many medical conditions, especially with the use of allogeneic therapies where the cells from a single donor can be used to treat ailments in many patients. Human mesenchymal stem cells (hMSCs) are promising for such therapies given their ability to grow in stirred bioreactor which are the most likely candidate for large scale production. Many of the process requirements that the stirring must achieve are typical of all bioreactors; namely adequate homogeneity with respect to nutrients, metabolites, temperature and $\mathrm{pH}$; and mass transfer of $\mathrm{O}_{2}$ into the media and $\mathrm{CO}_{2}$ out. There are also a number of special features; firstly, the cells are the product rather than the agent for making a product such as a therapeutic protein; and secondly, they have to be grown attached to a surface. To provide sufficient surface area to make growth in a stirred bioreactor efficient, small particles (microcarriers), typically of $\sim 200 \mu \mathrm{m}$, are added to it. Thus, particle suspension becomes important. Also, like all animal cells, hMSCs do not have a cell wall and are potentially damageable due to agitation; and the larger the entity in suspension compared to the Kolmogorov scale of turbulence, the greater the likelihood of damage. Thus, cells which in free suspension are 15-18 $\mu \mathrm{m}$ are now exposed to greater stresses due to their position on the surface of $\sim 200 \mu \mathrm{m}$ microcarriers. Cells may also be damaged or stripped off the surface of the microcarrier by microcarrier-impeller or microcarrier-microcarrier impacts. So the specific energy dissipation rate, $\varepsilon_{T}$, used during culture must be kept low. This approach suggests that operation at the minimum agitation speed for suspension should be adopted initially as a suitable strategy, especially has higher speeds lead to only small increases in mass transfer to particles [1].

Whilst there is significant focus in the literature on cell growth, there is little on the detachment or harvesting of the cells except at extremely small scales. Typically, cell detachment from microcarriers is by enzymatic digestion [2] aided by extensional flow using a pipette. At larger scales, such an approach becomes impractical and in addition, the enzymes can also damage the cells if exposure is prolonged. Thus, a new method is required. Given the sensitivity of particles of the size of microcarriers to abrasion (or if crystals, to secondary nucleation [3]), it was decided to try enhances the action of the enzyme by a short period of intense agitation at agitator speeds significantly greater than $N_{J S}$.

This paper reports these two approaches to culture and detachment in 4 different bioreactors, $15 \mathrm{~mL}$ ambr $^{\mathrm{TM}}$ (TAP Biosystems) (Figure 1), $125 \mathrm{~mL}$ spinner flasks (Figure 2), $250 \mathrm{~mL}$ DASGIP bioreactor (Eppendorf) (Figure 3) and a 5 L Sartorius Stedim bioreactor (Figure 4).

Figure 1 The $15 \mathrm{~mL}$ ambr $^{\mathrm{TM}}$ bioreactor (63 mm high x $31 \mathrm{~mm}$ wide $\mathrm{x} 18 \mathrm{~mm}$ deep) 
Figure 2 The $125 \mathrm{~mL}$ spinner flask

Figure 3 The $250 \mathrm{~mL}$ DASGIP bioreactor and impeller

Figure 4 The 5 L Sartorius Stedim bioreactor.

\section{THEORY}

\section{Damage to cells on microcarriers}

During culture at $N_{J S}$, the mean specific energy dissipation rate, $\left(\bar{\varepsilon}_{T}\right)_{J S}$ (numerically equal to the specific power, $(P / M)_{J S}$, imparted to the medium) is given by:

$$
\left(\bar{\varepsilon}_{T}\right)_{J S}=(P / M)_{J S}=P o \rho_{L} N_{J S}^{3} D^{5} / M_{J S}
$$

where $P o$ is the impeller power number (dependent on the impeller type), $D$ is the impeller diameter and $M_{J S}$ is the mass of medium and microcarriers in the vessel. Though there are some issues over the use of Kolmogorov's theory of isotropic turbulence because the Reynolds numbers, $R e$, are in the transitional regime $\left(\sim 10^{3}<R e<\sim 10^{4}\right)$, it is the standard approach for considering the impact of fluid dynamic stress on organisms [4]. It suggests that provided the size of the biological entity, $d_{E}$, which is suspended in the flow, is less than the Kolmogorov scale, $\lambda_{K}$, the entity should not be damaged where

$$
\left(\lambda_{K}\right)_{J S}=\left(v^{3} /\left(\varepsilon_{T}\right)_{J S \max }\right)^{1 / 4}
$$

where $\varepsilon_{T \max }$ is the maximum local $\varepsilon_{T}$ close to an impeller and $v$, the kinematic viscosity. In addition,

$$
\varepsilon_{T \max }=\Phi \bar{\varepsilon}_{T}
$$

where $\Phi$ depends rather weakly on the impeller type (it is similar with both so-called 'high shear' Rushton turbines and 'low shear' hydrofoil impellers [5]) and more on impeller diameter/vessel diameter ratio, $D / T$ [5]. For cells on microcarriers, $d_{E}$ is considered to be the size of the microcarrier, $d_{\text {micro }}$, typically $\sim 200 \mu \mathrm{m}$, and earlier work showed that cell growth is not compromised provided $\lambda_{K} \geq \sim 0.6 d_{\text {micro }}[4,6]$.

There is little literature on cell damage from microcarriers by impact with other microcarriers or with the rotating impeller. On the other hand, much has been done in relation 
to damage to crystals (secondary nucleation) from such mechanisms [3]. Details of the models are beyond the scope of this paper but in essence they suggest that 'damage' (whether destroying cells or just removing them from microcarriers) are relatively very sensitive to $\bar{\varepsilon}_{T}$. For example, for microcarrier-impeller impacts, the potential for damage, $D_{M-I}$ is related to the agitation parameters by the functionality,

$$
D_{M-I} \propto \bar{\varepsilon}_{T} N
$$

whilst for microcarrier-microcarrier impacts, the potential for damage, $D_{M-M}$ is related to agitation by;

$$
D_{M-M} \propto \bar{\varepsilon}_{T}^{1.5}
$$

The precise formulation of these equations is not important. What is important is that the impact mechanisms are very sensitive to agitator speed. Thus;

$$
D_{M-I} \propto N^{4}
$$

and

$$
D_{M-M} \propto N^{4.5}
$$

\section{Cell detachment}

The above theoretical relationships [3] suggest that increases in agitator speed above $\mathrm{N}_{\text {JS }}$ should lead to substantial increases in the impact mechanisms which could remove cells from microcarriers. However, once the cells are detached and become freely suspended, damage to the cells from these mechanisms does not occur because they are too small $(\sim 15-$ $18 \mu \mathrm{m})$ compared to the Kolmogorov scale [7]. Thus, Equ 2 becomes

$$
\left(\lambda_{K}\right)_{D}=\left(v^{3} /\left(\varepsilon_{T}\right)_{D \max }\right)^{1 / 4}
$$

and though $\left(\varepsilon_{T}\right)_{D \max }$ is larger, $\lambda_{K}>$ the cell size, so the cell should not be damaged [7,8]. 


\section{EXPERIMENTAL}

Cells were cultured at $37^{\circ} \mathrm{C}$ with a $\mathrm{pH}$ of $\sim 7$ maintaining $100 \% \mathrm{dO}_{2}$ by headspace aeration in the four different agitated bioreactors at $N_{J S}$ as measured visually (see Table 1). The smallest was $15 \mathrm{~mL} \mathrm{ambr}^{\mathrm{TM}}$, which is shown in Fig. 1 [8]. The second was a $125 \mathrm{~mL}$ unbaffled spinner flask (Fig. 2) [4] and the other two were both cylindrical bioreactors of 250 mL (DASGIP) (Fig. 3) and 5 L (Sartorius Stedim) (Fig. 4). Further details of the procedure are given elsewhere [7].

After carefully removing the growth media by pipette, detachment was undertaken insitu by the addition of an enzyme solution to the microcarriers with cells still attached and then agitating intensively for 7 minutes at the speeds given in Table 1. Subsequently, the cells were removed from the microcarriers by using a Steriflip ${ }^{\circledR} 60 \mu \mathrm{m}$ filtration unit (Millipore, UK) so that the cells and suspending fluid passed through and the microcarriers remained in the filter. Further details are again given elsewhere [9].

In all cases after both culture and harvesting, in order to identify whether there had been any change in the hMSCs as a result of their treatment, they were analysed: 1) according to the International Society of Cell Therapy (ISCT) panel of markers to ascertain their immunophenotypic expression; 2) by tissue-culture adherence and morphology; and 3) for their multilineage differentiation potential $[7,8]$. All were appropriate showing that the cells maintained the desired quality attributes for therapeutic usage. In addition, the post-harvest viability of the cells as determined by a Nucleocounter NC-3000 (Chemometec, Denmark) was always $>95 \%$.

Table 1. Agitation Parameters During Culture and Detachment

\section{RESULTS AND DISCUSSION}

\section{The Kolmogorov scale at $\mathbf{N}_{\text {JS }}$ during culture in each bioreactor.}

Taking each bioreactor in the order of Table 1, the shape of the $15 \mathrm{~mL}^{\mathrm{ambr}}{ }^{\mathrm{TM}}$ together with the flow patterns generated by the impeller [9] makes it difficult to prevent the microcarriers settling in the corners, especially those furthest away from the impeller. Cells tend to attach preferentially there, forming cell aggregates which increase as the culture progresses. The small scale leads to a high agitation speed [10] but the characteristics of the $\operatorname{ambr}^{\mathrm{TM}}$ enhance it further, leading to a high $\bar{\varepsilon}_{T}$. Estimating $\Phi$ as 18 [5] based on the equivalent diameter of the $\operatorname{ambr}^{\mathrm{TM}}$ vessel [9] (giving $D / T=0.48$ ) gives $\left(\varepsilon_{T}\right)_{J S \max }=0.14 \mathrm{~W} / \mathrm{kg}$ and the Kolmogorov scale, $\left(\lambda_{K}\right)_{J S}=52 \mu \mathrm{m}$. Thus, $\left(\lambda_{K}\right)_{J S}=\sim 0.25 d_{\text {micro }}$, much smaller than has 
generally been considered acceptable for satisfactory culture on microcarriers $[4,6,7,8]$. Yet the cells grew well (data not shown) and maintained their quality attributes.

With the unbaffled spinner flasks, $\bar{\varepsilon}_{T}$ is low, probably because of the large $D / T(\sim 0.7)$ radial flow impeller [10]; and because the depth of the impeller means that as it rotates, it moves in a volume almost equal to that of the medium in the vessel. For this large $D / T$ ratio, $\Phi$ has been estimated to be 10 [5], giving $\left(\varepsilon_{T}\right)_{J S \max }=6.3 \times 10^{-3} \mathrm{~W} / \mathrm{kg}$ and $\left(\lambda_{K}\right)_{J S}=112 \mu \mathrm{m}$. This value is much closer to the size suggested in the earlier work indicating that $\lambda_{K}$ should be $>\sim 0.6$ times the size of the microcarrier for satisfactory culture [6].

The DASGIP is also unbaffled but has probes in it, which produce some baffling. The axial flow impeller is effective for suspension at $D / T=0.48$ [10] giving $N_{J S}=1.92 \mathrm{rev} / \mathrm{s}$. Estimating $\Phi$ as 18 [5] for this $D / T$ ratio gives $\left(\varepsilon_{T}\right)_{J S \max }=0.046 \mathrm{~W} / \mathrm{kg}$ and $\left(\lambda_{K}\right)_{J S}=68 \mu \mathrm{m}$, bigger than with the $\operatorname{ambr}^{\mathrm{TM}}$ but still smaller relative to the size of the microcarrier than is generally expected for good growth. Finally, for the $5 \mathrm{~L}$ Sartorius bioreactor [7] with $D / T=$ 0.43 giving $\Phi=25$ [5], $\left(\varepsilon_{T}\right)_{J S \max }=0.049 \mathrm{~W} / \mathrm{kg}$ and $\left(\lambda_{K}\right)_{J S}=67 \mu \mathrm{m}$. Thus, for these two fairly similar geometry bioreactors, the agitation parameters that determine the potential for damage, namely $\left(\varepsilon_{T}\right)_{J S \max }$ and $\left(\lambda_{K}\right)_{J S}$ are very similar. Again the cells grew well [7].

\section{The Kolmogorov scale during detachment in each bioreactor}

For the $15 \mathrm{~mL}$ ambr ${ }^{\mathrm{TM}}, N_{J S}$ and especially $\left(\varepsilon_{T}\right)_{J S \max }$ were very high leading to a relatively small $\lambda_{K}$ compared to the size of the microcarrier. Thus, a detachment speed, $N_{D}=$ $2 N_{J S}$ was first chosen (Table 1), which increases the higher detachment parameter by 35 times greater than during cultivation. Detachment was successful (Figure 5) with $\left(\varepsilon_{T}\right)_{D \max }=2.8$ $\mathrm{W} / \mathrm{kg}$ and $\left(\lambda_{K}\right)_{D}=24 \mu \mathrm{m}$, somewhat greater than the size of the detached cells. The cells maintained the hMSC quality attributes with a viability $>95 \%$. Subsequently, the speed was reduced (see Table 1) to give $\left(\varepsilon_{T}\right)_{D \max }$ approximately equal to that parameter in the other bioreactors. Detachment was again successful.

Figure 5 SoloHill Plastic Microcarriers: a) with cells attached as indicated by red arrows; b) 'clean' microcarriers (A) after cells (B) have been detached.

For the spinner flask, because $\left(\varepsilon_{T}\right)_{J S \max }$ was so low, $N_{D}=5 N_{J S}$ was chosen, increasing the higher detachment parameter by up to $\sim 1400$ times that used during cultivation to give $\left(\varepsilon_{T}\right)_{D \text { max }}$ approximately equal to the lower value used with the $\operatorname{ambr}^{\mathrm{TM}}(1.31 \mathrm{~W} / \mathrm{kg})$, to give 
$\left(\lambda_{K}\right)_{D}=30 \mu \mathrm{m}$. Thus, again, $\left(\lambda_{K}\right)_{D}$ was greater than the size of the detached cell and detachment was successfully achieved with the cells maintaining their quality attributes.

For the DASGIP, initially an agitation speed $\sim 5 N_{J S}$ as with spinner flasks was used but it caused severe surface bubble entrainment, perhaps because of the lack of proper baffling. As a result, $\mathrm{N}_{\mathrm{D}}$ was reduce to $\sim 3.25 N_{J S}$ to avoid this phenomenon, which also gave $\left(\varepsilon_{T}\right)_{D \max }=2.23 \mathrm{~W} / \mathrm{kg}$, a similar value to that in the two smaller vessels; and $\left(\lambda_{K}\right)_{D}=26 \mu \mathrm{m}$. Once again, successful detachment was achieved.

The volume of media used in the 5L bioreactor was too great to be treated in the Steriflip but detachment was achieved by using the spinner flasks sequentially as above.

\section{CONCLUSIONS}

These two agitation strategies offer a useful approach to the scale-up of stem cell culture, at least until much higher cell densities are achieved when $\bar{\varepsilon}_{T}$ required to give adequate oxygen transfer of may not be sufficient at $N_{J S}$. Nevertheless, with cells growing at $\left(\lambda_{K}\right)_{J S}=\sim 30 \%$ of the microcarrier size, it may be that, as with animal cells in free suspension [9], hMSCs are more robust than has generally been perceived.

\section{ACKNOWLEDGEMENTS}

The authors would like to acknowledge the UK Engineering and Physical Sciences Research Council (EPSRC), Lonza Cologne AG and FujiFilm Diosynth Biotechnologies for funding. 


\section{NOTATION}

$d$--- particle diameter, $\mathrm{m}$

$D$--- impeller diameter, $\mathrm{m}$

$M$--- mass in vessel, $\mathrm{kg}$

$N---$ agitator speed, rev/s

$P$--- power input, $\mathrm{W}$

Po --- power number, dimensionless

Re ---Reynolds number $\left(N D^{2} / \mathrm{v}\right)$, dimensionless

$T---$ bioreactor diameter, $\mathrm{m}$

$\varepsilon_{T}---$ local specific energy dissipation rate, $\mathrm{W} / \mathrm{kg}$ or $\mathrm{m}^{2} / \mathrm{s}^{3}$

$\bar{\varepsilon}_{T}$--- mean specific energy dissipation rate, $\mathrm{W} / \mathrm{kg}$ or $\mathrm{m}^{2} / \mathrm{s}^{3}$

$\lambda_{K}---$ Kolmogorov scale of turbulence, $\mathrm{m}$

$v$--- kinematic viscosity, $\mathrm{m}^{2} / \mathrm{s}$

$\Phi---\left(\varepsilon_{T}\right)_{\max } / \bar{\varepsilon}_{T}$, dimensionless

$\rho_{L}---$ fluid density, $\mathrm{kg} / \mathrm{m}^{3}$

SUBSCRIPTS

D --- during detachment

E --- biological entity

JS --- at the just suspended condition

max --- maximum

micro --- microcarrier

M-M --- microcarrier-microcarrier impacts

M-I--- microcarrier-impeller impacts 


\section{REFERENCES}

[1] Nienow A.W., The mixer as a reactor-liquid/solid systems, in Mixing in the Process Industries, N. Harnby, M.F. Edwards, A. W. Nienow, Eds., London: Butterworth Heinemann, 1997, ch. 17, 2nd paperback edn.

[2] Weber C, Pohl S., Pörtner R., Wallrapp C., Kassem M., Geigle P. and Czermak P., Expansion and harvesting of hMSC-TERT, Open Biomed. Eng. J., 2007, vol. 1, p. 38.

[3] Nienow A.W.and Paul E.L., Mixing Issues in Crystallization and Precipitation Operations, in Advances in Industrial Mixing: A Companion to the Handbook of Industrial Mixing, (Kresta, S.M., Etchells III, A.W., Dickey, D.S., Atiemo-Obeng, V. Eds., New York, USA: Wiley-Interscience, 2015, ch. 25.

[4] Hewitt C.J., Lee, K., Nienow, A.W., Thomas, R.J., Smith, M. and Thomas, C.R., Expansion of human mesenchymal stem cells on microcarriers, Biotechnol. Lett., 2011, vol. 33, p. 2325.

[5] Zhou, G. and Kresta, S.M., Impact of tank geometry on the maximum turbulence energy dissipation rate for impellers", AIChE J., 1996, vol. 42, p. 2476.

[6] Croughan, M.S., Hamel, J.F. and Wang, D.I.C, Hydrodynamic effects on animal cells grown in microcarrier cultures, Biotechnol. Bioeng., 1987, vol. 29, p. 130.

[7] Rafiq, Q.A., Brosnan, K.M., Coopman, K, Nienow, A.W. and Hewitt, C.J., Culture of human mesenchymal stem cells on microcarriers in a $5 \mathrm{~L}$ stirred tank bioreactor, Biotechnol. Lett., 2013. Vol. 35, p. 1233.

[8] Nienow, A.W., Rafiq, Q.A., Coopman, K., and Hewitt, C.J., A potentially scalable method for the harvesting of hMSCs from microcarriers, Biochem. Eng. J., 2014, vol. 85, p. 79.

[9] Nienow, A.W., Rielly, C.D., Brosnan, K.M., Bargh, N., Lee, K., Coopman, K. and Hewitt, C.J., The phyical characterisation of a microscale parallel bioreactor platform with an industrial CHO cell line expressing an IgG4, Biochem. Eng. J., 2013, vol. 76, p. 25.

[10] Ibrahim S. and Nienow, A.W., Suspension of microcarriers for cell culture with axial flow impellers. Chem. Eng. Res. Des., 2004, vol. 82, p. 1082. 


\begin{tabular}{|c|c|c|c|c|c|c|c|c|c|}
\hline \multirow{2}{*}{$\begin{array}{l}\text { Culture } \\
\text { Platform }\end{array}$} & \multirow{2}{*}{$\begin{array}{c}\text { Culture } \\
\text { volume/ } \\
\text { Detachment } \\
\text { volume }\end{array}$} & \multirow{2}{*}{$\begin{array}{c}\text { Power } \\
\text { no., } \\
P o l \\
\Phi^{1}\end{array}$} & \multirow{2}{*}{$\begin{array}{l}D(\mathrm{~m}) / \\
T(\mathrm{~m})\end{array}$} & $N_{J S}\left(\mathbf{s}^{-1}\right)$ & $\begin{array}{l}\left(\varepsilon_{T}\right)_{\text {JSmax }} \\
(\mathrm{W} / \mathrm{kg})\end{array}$ & $\begin{array}{c}\left(\lambda_{K}\right)_{J S} \\
(\mu \mathrm{m})\end{array}$ & $N_{D}\left(\mathbf{s}^{-1}\right)$ & $\begin{array}{c}\left(\varepsilon_{T}\right)_{D \max } \\
(\mathrm{W} / \mathrm{kg})\end{array}$ & $\begin{array}{c}\left(\lambda_{K}\right)_{D} \\
(\mu \mathrm{m})\end{array}$ \\
\hline & & & & \multicolumn{3}{|c|}{ Expansion parameters } & \multicolumn{3}{|c|}{ Detachment parameters } \\
\hline $\begin{array}{c}15 \mathrm{~mL} \\
\text { TAP } \\
\mathrm{ambr}^{\mathrm{TM}}\end{array}$ & $\begin{array}{c}15 \mathrm{~mL} / \\
6 \mathrm{~mL}\end{array}$ & $\begin{array}{c}2.1^{2 /} \\
18\end{array}$ & $\begin{array}{l}0.011 / \\
0.023\end{array}$ & 6.67 & 0.142 & 52 & $\begin{array}{l}13.3 / \\
/ 10.8\end{array}$ & $\begin{array}{c}2.83 / \\
1.50\end{array}$ & $24 / 29$ \\
\hline $\begin{array}{c}125 \mathrm{~mL} \\
\text { spinner } \\
\text { flask }\end{array}$ & $\begin{array}{c}100 \mathrm{~mL} / \\
60 \mathrm{~mL}\end{array}$ & $\begin{array}{c}1.0^{3 /} \\
10\end{array}$ & $\begin{array}{r}0.055 / \\
\sim 0.08\end{array}$ & 0.5 & 0.0063 & 112 & 2.5 & 1.31 & 30 \\
\hline $\begin{array}{c}250 \mathrm{~mL} \\
\text { DASGIP } \\
\text { bioreactor }\end{array}$ & $\begin{array}{c}100 \mathrm{~mL} / \\
70 \mathrm{~mL}\end{array}$ & $\begin{array}{c}1.5^{4} / \\
18\end{array}$ & $\begin{array}{l}0.030 / \\
0.063\end{array}$ & 1.92 & 0.046 & 68 & 6.25 & 2.23 & 26 \\
\hline $\begin{array}{c}5 \mathrm{~L} \\
\text { Sartorius } \\
\text { bioreactor }\end{array}$ & $\begin{array}{c}2.5 \mathrm{~L} / \\
\mathrm{NA}\end{array}$ & $\begin{array}{c}1.5^{5 /} \\
25\end{array}$ & $\begin{array}{c}0.070 / \\
0.16\end{array}$ & 1.25 & 0.049 & 67 & NA & NA & NA \\
\hline
\end{tabular}

1) Estimated from reference [5]; 2) From reference [9]; 3) From reference [4]; From reference [7] since agitators in the DASGIP and Sartorius bioreactors are similar 3 blade, pitched turbines; 5) From reference [7]

Table 1 
Figure captions

Figure 1 The $15 \mathrm{~mL}$ ambr ${ }^{\mathrm{TM}}$ bioreactor (63 mm high $\mathrm{x} 31 \mathrm{~mm}$ wide $\times 18 \mathrm{~mm}$ deep)

Figure 2 The $125 \mathrm{~mL}$ spinner flask

Figure 3 The $250 \mathrm{~mL}$ DASGIP bioreactor and impeller

Figure 4 The 5 L Sartorius Stedim bioreactor.

Figure 5 SoloHill Plastic Microcarriers: a) with cells attached as indicated by red arrows; b) 'clean' microcarriers (A) after cells (B) have been detached. 


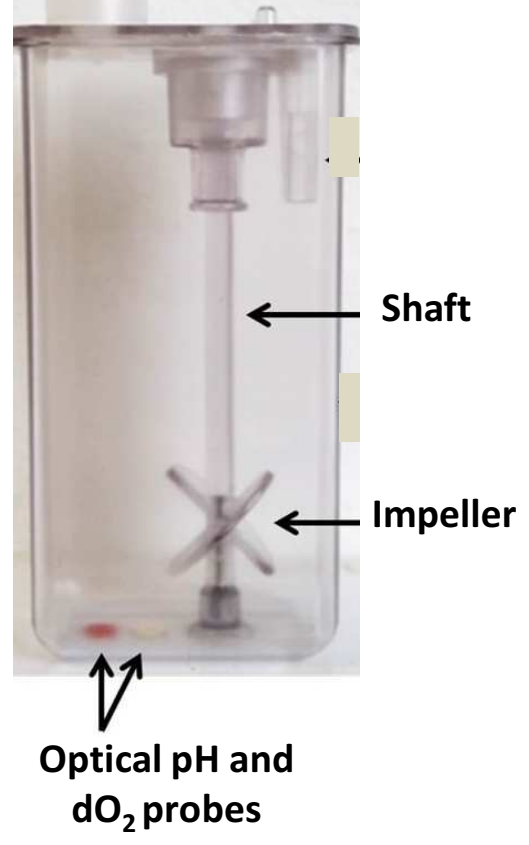

Figure 1 


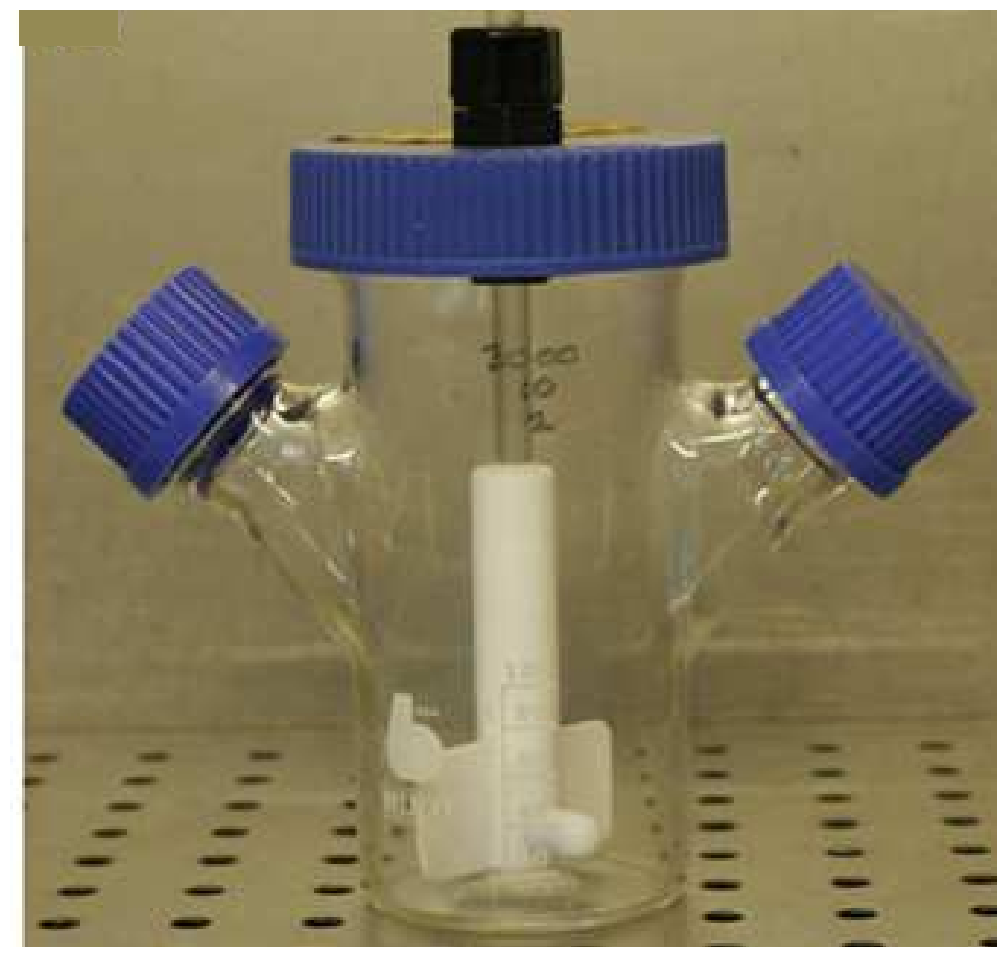

Figure 2 


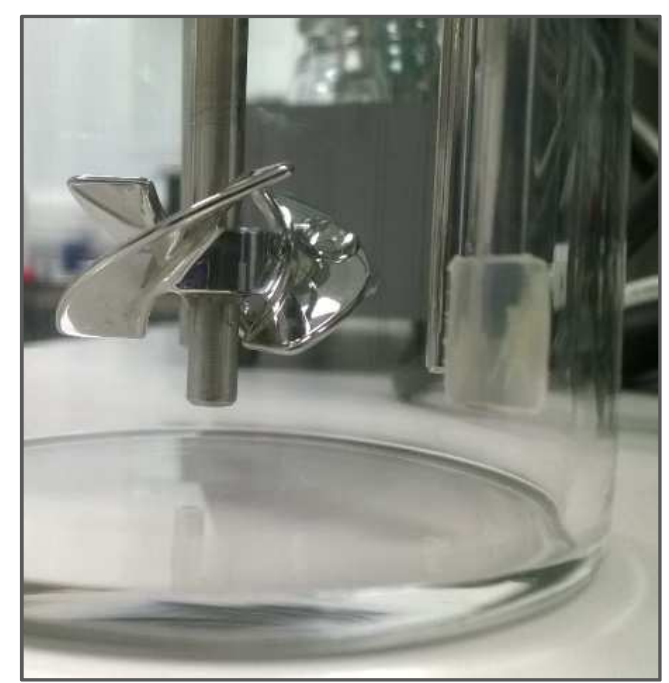

Figure 3 


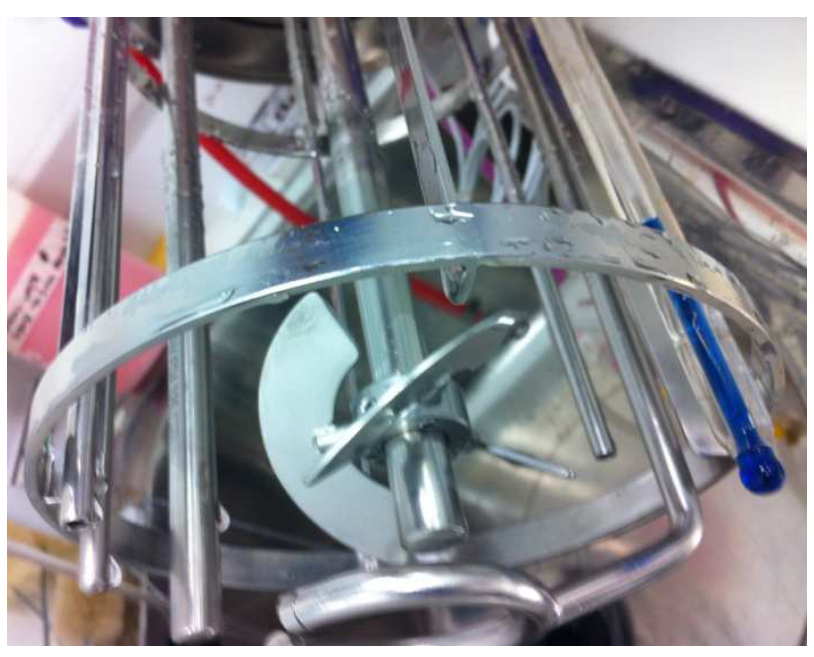

Figure 4 


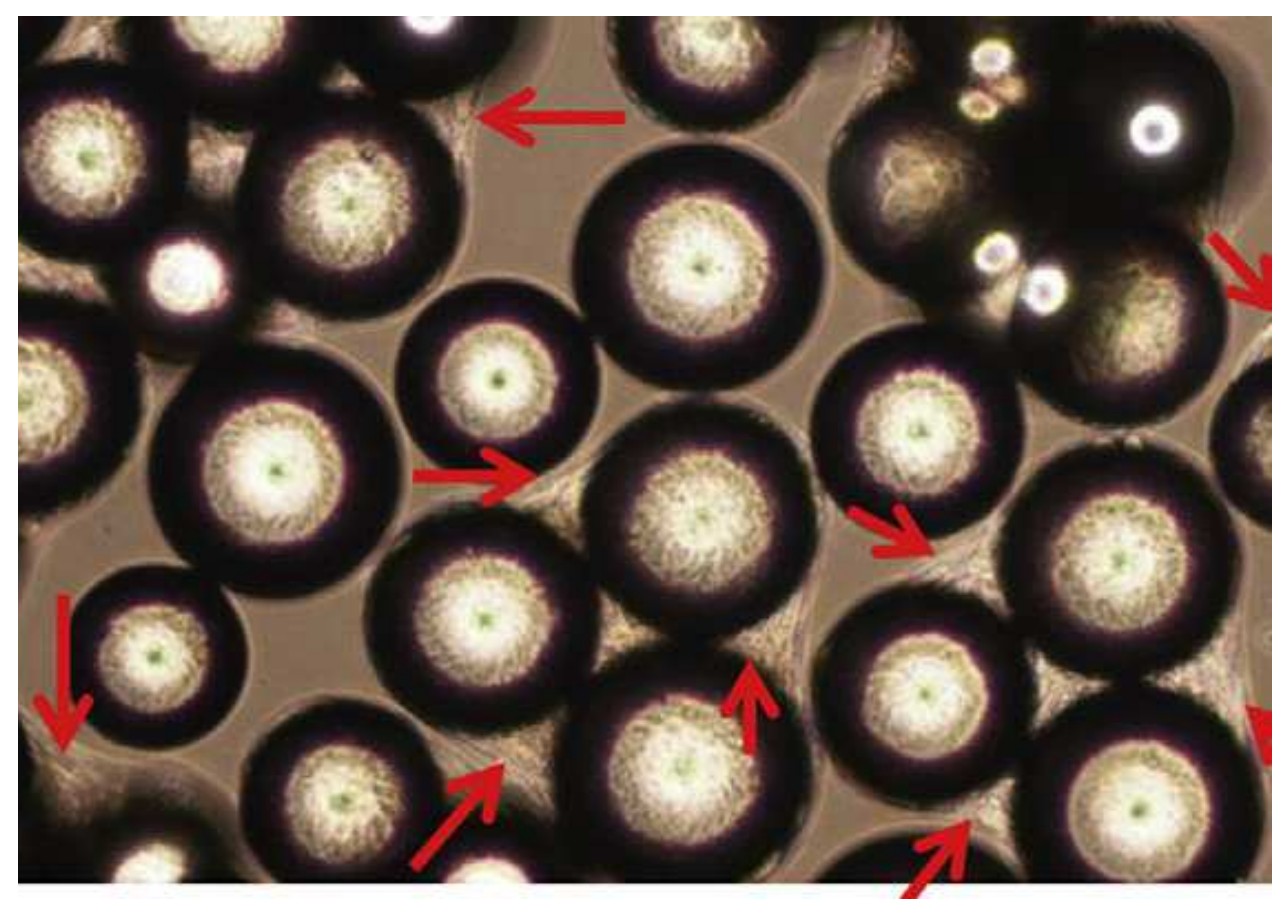

Figure 5a

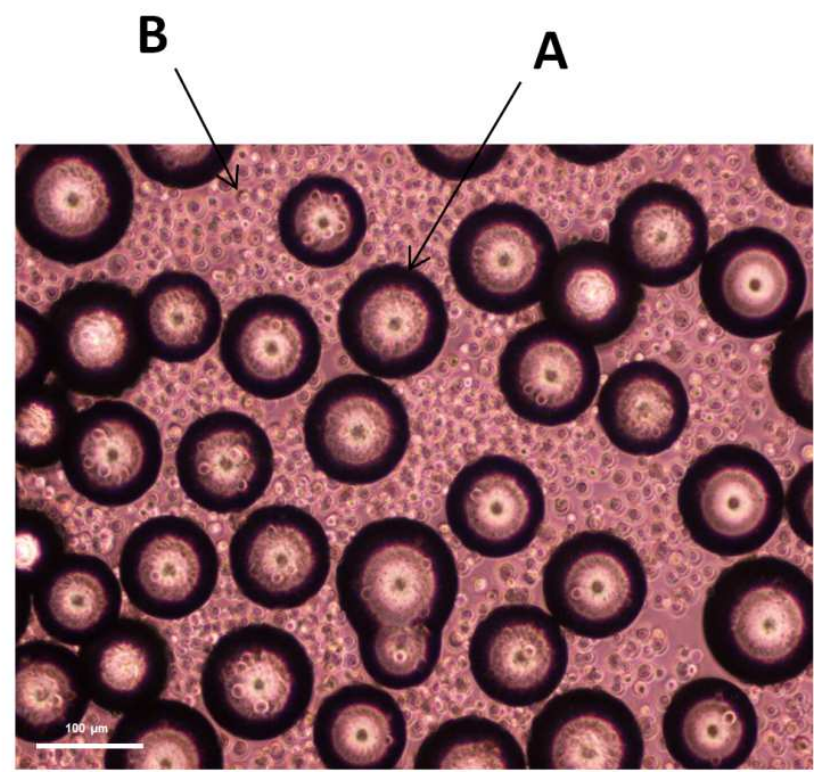

Figure $5 b$ 